\title{
最近の電力ケーブル技術の動向について
}

上級会員 戸谷＼cjkstart敦*

\section{Overview of Present Technology of Power Cable}

Atsushi Toya*, Senior Member

Power cable has been used widely for power supply in the urban area. This article describes the importance, present status and future perspectives about the technology of power cable.

キーワード : OF ケーブル, CV ケーブル，リプレース，診断

Keywords: OF cable, XLPE cable, replace, diagnosis

\section{1. はじめに}

電力ケーブルは都市部などへの電力供給設備として広く 用いられているが，最近まで続いていた平成不況により電 線業界は工事量が落ち込んだ。今後の電力需要の伸びは人 口減や省エネ効果により鈍化の方向であるが，電気使用量 は電化率のアップや景気回復と共に増えてきており，今後 設備の新増設が徐々に増加するものと期待されている。

その一方，いざなぎ景気に代表される高度成長期に建設 された電力ケーブル設備が経年 30, 40 年を超え, 各種劣 化現象により機能低下を起こし始めている。このため電力 などのユーザ会社においては，設備体質を評価するための 手法としてケーブル劣化診断を導入して既設設備を最大限 活用したり, 劣化設備の順次引替えを行う，いわゆるリプ レース工事も始まっている。また電力自由化に伴い電気料 金の值下げが求められており，設備維持に必要な支出を最 大限少なくするための方策が必要となっている。このため 設備品質を維持しながらも継続的な設備原価低減を図って いくために，適切なリプレース実施時期の見極めや工事 . 保全費用の更なるコストダウンに向けた技術開発・導入が 急務となっている。

本稿では，最近の送電用電力ケーブルに関する技術動向 について概観してみたい。

\section{2. 国内外の電カケーブルに関する技術動向}

$\mathrm{CV}$ ケーブルは OF ケーブルに比べて, 給油設備が不要で かつ防災性能に優れていると共に施工・保守管理が容易で あることから，その適用が世界的に進み現在では国内電力会

\footnotetext{
東京電力 (株)

干 100-8560 東京都千代田区内幸町 1 丁目 1 番 3 号

Tokyo electric Power Company

1-3, Uchisaiwai-cho 1-chome, Chiyoda-ku, Tokyo 100-8560
}

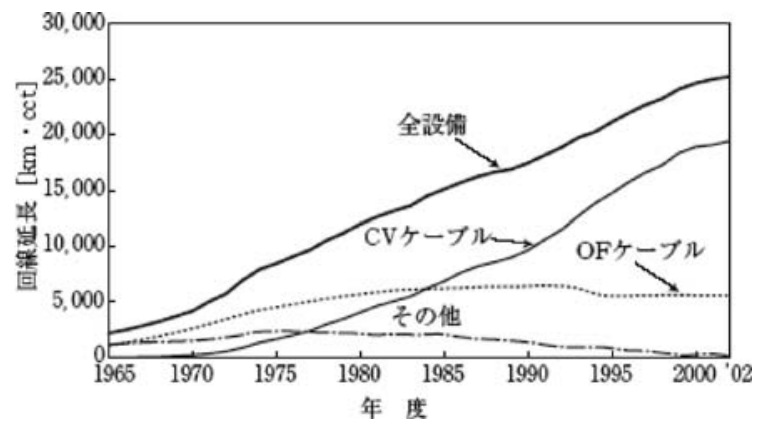

図 1 ケーブル種類別の設備量の推移 $(22 \mathrm{kV}$ 以上)

Fig. 1. Change of amount classified by cable type (more than $22 \mathrm{kV}$ ).

社の電力ケーブル設備量 $(22 \mathrm{kV}$ 以上) の 8 割が CV ケーブ ルとなっている（図 1)。また 1960 年代後半に $66 \mathrm{kV}$ へ適 用されて以降, 高電圧化および大容量化が急速に進み, 2000

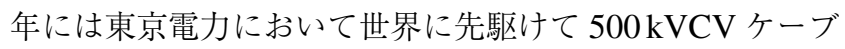
ル長距離送電線が運転を開始している。

このように, 送電用ケーブルにおいては $\mathrm{OF}$ 時代から $\mathrm{CV}$ 時代へ, そして CV の高電圧化を主体とした技術開発が行 われてきたが, 今後も CV ケーブルを主体に, ケーブルの コンパクト化や接続技術の簡素化・スキルレス化, 付帯設 備の高度化などの改良検討が行われるものと想定される。

〈2・1〉設備運用面の技術動向最近において設備の 有効活用の観点から, 既設設備の高稼働化を要求される機 会が増えてきた。それに伴い，ケーブルの高温領域におけ る各種性能に関するデータや知見も相当蓄積されてきたが, 1998 年に電気学会電力技術委員会の下に「ケーブルの高温 性能に関する技術調査専門委員会」が設立され, OF, CV ケーブルの高温領域における絶縁性能の各種限界值に関す る技術的なデータが取り䌂められている ${ }^{(1)}$ 。今後も高温使 
用のニーズは高まってくるものと思われるが，ケーブル並 びに接続部の長時間劣化データを始め未解明な部分もあり, 今後も継続的な調査研究を進めていくことが望まれる。

これに関連して，1998 年ニュージーランドのオークラン ド市における大停電発生 (ケーブルの温度管理の不備により 次々とケーブルが絶縁破壊を起こしたことが原因) 後, ケー ブル温度を監視しながら電流管理する手法（ダイナミック レイティング）が各国で採用され始めている。具体的には, 光ファイバ温度センサをケーブル内またはケーブルの表面 に施設し，常時温度管理を行いながらケーブルの導体温度 （許容電流）を自動計算して電流管理するというものであ る。日本では，電流運用を予め予測した上でその最大電流 を基にケーブルサイズを選定し，そのマージン内で管理す れば良いという立場で運用している。今後土壌環境の変化 に合わせた温度管理システムの必要性やメンテナンス性能 などを十分に勘案しながら検討していくべき事項である。

また設備管理の高度化に向け，光ファイバ温度センサの 他, 光鉛ガラスを用いた事故検出システム ${ }^{(2)}$ など光技術を用 いた弱電システムの適用事例も増えている。更に東京電力 などにおいては有限要素法解析手法を用いた高精度なケー ブル送電容量計算プログラムの開発 ${ }^{(3)}$ も行われている。こ れら送電容量をはじめ電力設備管理の高度化については, 弱電システムやコンピューター技術の進歩と共に進展して いくものと思われる。

$\langle\mathbf{2} \cdot 2\rangle$ ケーブル・接続部仕様に関する技術動向 今後 経年設備のリプレース工事が増えるものと思われるが，コ ストダウンや機能向上を図る上で仕様の見直しや新技術の 開発・導入が求められている。ここでは，最近の主な検討 事例について述べる。

（1）トリプレックス CV ケーブルの適用拡大 トリ プレックス型 CVケーブル (CVT) は日本固有の技術であ り，66kV 級以下の比較的小サイズケーブルに採用されて きた。最近，154kVにおいても既設管路の有効活用および ケーブル工事費の削減を狙いとして大サイズ $1,000 \mathrm{~mm}^{2}$ の CVT ケーブル採用が始まっている (4)。またこれに合わせ， 布設形態の技術検討を行うべく機械定数などの検証試験を 行っている。今後，大サイズ CVT ケーブルの布設設計の 合理化に向けて各種技術検討の充実化が望まれる。

（2）CV ケーブル用中間接続部の簡素化，スキルレス化 $\mathrm{CV}$ ケーブル用中間接続部は, 従来 $66 \mathrm{kV}$ 級以下はテー プ巻き式 $(\mathrm{TJ}), 154 \mathrm{kV}$ 級はテープ巻きモールド式 $(\mathrm{TMJ})$ が主流であった。モールド式はケーブルと同種材料を使用 するため，異種材料との界面が無く，コンパクトで高品質 な接続部が可能であることから，275 kV $500 \mathrm{kV}$ におい て押し出しモールド式 (EMJ) が実用化されている。それ と並行して，信頼性を確保しつつ，スキルレス化・施工時 間短縮，コストダウンを図るため，プレハブ式接続部 $(\mathrm{PJ})$ ならびに図 2 のゴムブロック式接続部 $(\mathrm{RBJ})$ の開発・適 用が行われている。PJについては 1990 年代より急速に普 及し， $275 \mathrm{kV}$ 線路への実用化が図られ，500 kV の長期課
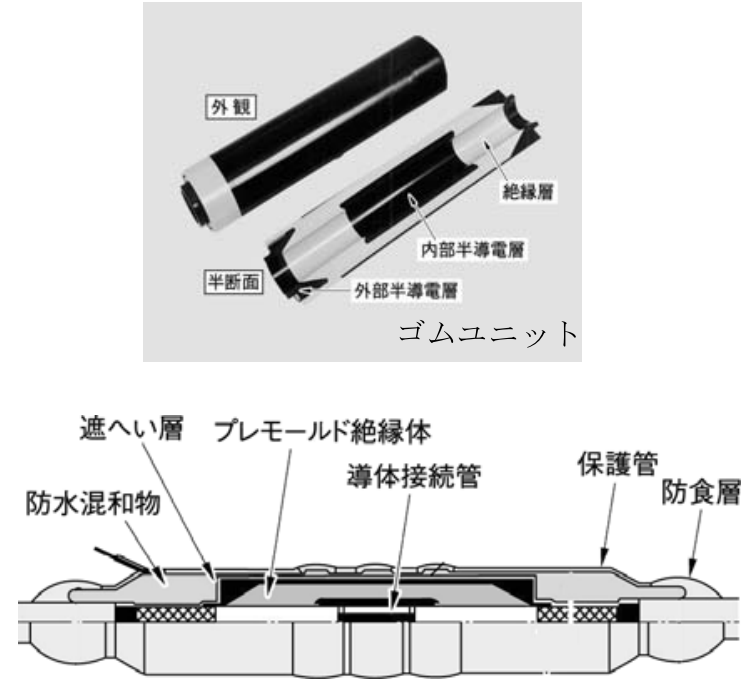

図 2 ゴムブロック式接続部 $(\mathrm{RBJ})$

Fig. 2. Rubber Block Joint (RBJ).

通電試験（開発試験）も終了している(5)。またPJ の技術を 応用した Y 分岐接続部が $275 \mathrm{kV}$ まで実用化されている。

ヨーロッパにおいても各主要都市部において $225 \mathrm{kV}$, $400 \mathrm{kV}$ 級 CV ケーブルの地中送電設備が増加しているが, 中間接続部は既に PJ や RBJ が主流になりつつある ${ }^{\left({ }^{(6)}\right.}$ 。

国内の RBJ については順次高電圧化が進められ，66 kV 級 (1999)，154kV 級 (2000) に現場適用が図られている。 RBJ のゴム材料にはエチレンプロピレンゴム（EPR）を使 用するタイプと，シリコーンゴムを使用するタイプがある。 前者はプレハブ式のストレスコーンで実績のある材料を使 用し, 後者は工場内で拡径することが可能で現地作業が簡 易であるという特色がある。

この RBJ については，更に現状よりスキルレス・施工時 間短縮化を狙った研究 (7) が進んでいる一方, 将来的には超 高圧線路にも RBJが採用されるものと想定され, 現時点か ら各部品の破壊電界や温度特性などの諸特性デー夕を整理 しておくことが必要である。また今後の適切な設備管理を 行っていく上で，ゴムの長期劣化など接続部の経年劣化現 象について現時点までに得られている知見を整理する必要 がある。こうした最近の CV ケーブル用接続部の諸特性や 劣化現象に関する技術的なデー夕を整理し充実化すること を目的として，電気学会電線・ケーブル技術委員会の下に 「送電用 CV ケーブル用接続部の技術動向調査専門委員会」 が設置され鋭意検討が進められている。

（3）ＣV ケーブル用終端接続部のコンパクト化と軽量 化終端接続部には主にガス中・気中の終端接続部があ る。これまでガス中終端接続部は, エポキシユニット+ゴ ムストレスコーンを利用したプレハブ絶縁方式が使用され, $220 \mathrm{kV}$ 以上では油浸夕イプが中心であったが，その後技術 革新により $220 \mathrm{kV}$ 以上でも油を使用しないプレハブ絶縁 タイプが主流となりつつある。また，最近では $66 \mathrm{kV}$ 級を 中心として部品点数を大幅に削減，コンパクト化を図った 


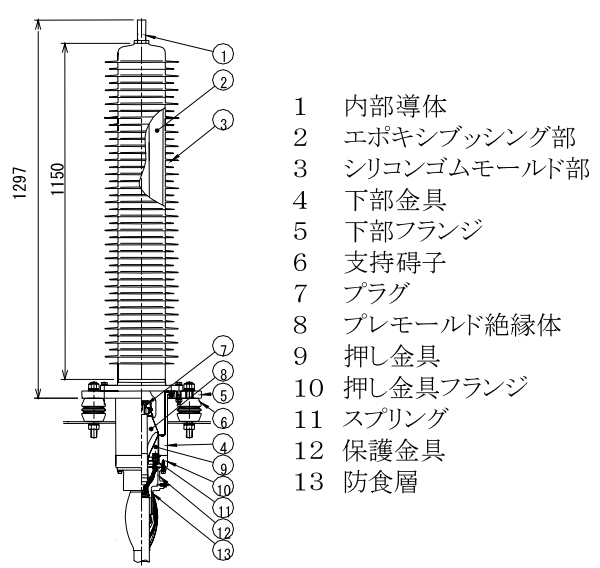

図 3 ポリマー碍管の例（中実タイプ）

Fig. 3. The example of polymer bushing (solid core type).

プレハブ絶縁タイプの製品も開発 ${ }^{(8)}$ され，機器との取り合 いが大幅に改善されつつある。

一方，気中終端接続部はこれまで磁器碍管を使用する油 浸タイプが使用されてきたが，近年の高分子絶縁材料の技 術進歩と共に，シリコーンゴムを碍管ひだ表面の材料に使 用したポリマー碍管が $66 \mathrm{kV}$ 級, $154 \mathrm{kV}$ 級に適用されるよ うになってきた ${ }^{(9)}$ 。ポリマー碍管の特徵として軽量，污損 に強い，耐震・防爆性に優れているなどの利点がある。国 内では架空線からの塔上分岐設備などへの適用例が多いが, 海外では磁器碍管のバンダリズム (破壊行為) 対策などと して急速にシェアを増やしつつある。

更に，ポリマー碍管の内部絶縁として RBJ の技術を応用 してゴムユニット差込式にすると共に，シリコーン油の代 わりに $\mathrm{SF}_{6}$ ガスを封入し，水平設置・下向き設置などどの ような角度でも設置できる夕イプも現地適用されている ${ }^{(10)}$ 。 また図 3 のように，内部にシリコーン油も $\mathrm{SF}_{6}$ ガスも入れ ないエポキシとアルミの中実タイプも開発され(11), 現地適 用されている。今後, 軽量化やコストダウンなどを狙いと してポリマー碍管の採用例が増えるものと思われるが，長 期污損特性などの把握に向けフィールドにおける点検・調 査を継続する必要がある。

（4） OF，POFケーブルのリプレース技術＼cjkstart経年 OF ケーブルや POF ケーブルのリプレースは今後 CV 化が基本 となるが，OF については線路運用や布設条件によって全 線路を一度にリプレースできない場合があり，途中に CV と OF の異種接続部を設置することになる。最近において， 既設マンホールに設置可能な $154 \mathrm{kV}$ 級コンパクト型異種 接続部などが開発されている。

また経年 POFケーブルのリプレースにおいては，既設の 鋼管を流用しケーブルを CV 化する方法が考えられる。そ の場合，POF 鋼管内に CV ケーブルを収めるためには絶縁 厚低減などにより外径を小さくする必要があると共に，そ れに合わせて接続部を開発する必要がある。また従来は油 の循環による冷却効果 (増容量) が期待できたが，CV 化
にした場合の増容量方式を新たに開発する必要がある。

英国やフランスなどにおいても，日本と同様に 1950 年 代， 60 年代に集中して構築した経年 OF ケーブルが増えて おり，それらのリプレース ( $\mathrm{CV}$ 化) が始まっている。しか しその殆どが直埋布設であるため，再度掘削を伴う大々的 な工事となったり新たにトンネルを新設したりすることで 相当な費用がかかっている。また既設埋設ケーブルの撤去 が思うようにできないなどの課題も発生している。その点, 日本においてはその多くの地中送電線路が管路または洞道 方式を採用しており，線路のリプレースはケーブルの引替 えのみで済むためコスト的にも有利であると考えられる。

（5）新しいケーブルの開発＼cjkstart超電導ケーブルは，超 電導導体を用いることによる低損失化, 高電流密度化を困 ることができ，既存の超高圧ケーブルと同等以上の送電容 量を $66 \mathrm{kV}$ 級のケーブルで実現できる技術として国内外で 期待されている。国内においては，高温超電導の三相一括 型ケーブルによるフィールド試験 ${ }^{(12)}$ ，世界最長の $500 \mathrm{~m}$ 級 ケーブルによるフィールド試験 ${ }^{(13)}$ が成功しており，今後の 実用化に向けて大きく前進した。今後更に，常温超電導の 開発や線材の長尺化技術，中間接続部・長距離冷却技術な どの開発が望まれる。

また将来，軽量化・低損失化を図ったケーブル（導電性プ ラスチックなど) や，ケーブル布設・接続の自動化 (ロボッ 卜施工), 環境にやさしいケーブル (完全リサイクル型)，イ ンテリジェント型ケーブル（布設位置や劣化状況が把握可 能な情報発信型ケーブル）などの開発が期待される。

\section{$\langle\mathbf{2} \cdot \mathbf{3}\rangle$ 保全に関する技術動向}

（1） OF ケーブルの保全技術ＯF ケーブルの寿命は 概ね金属被の疲労による漏油発生によって決まる。鉛被 OF ケーブルは布設後 40 年を超えているものが多く (図 4), 既にそれらのケーブルにおいて漏油が多発していることか ら，順次引替が行われている。一方アルミ被 OF ケーブル においては，通常の運転下で防食層が健全であれば 50 年 程度の寿命は期待できることから，多くの電力会社におい ては接続部からの絶縁油分析による診断を行いながら設備 の延命管理に努めている。

その一方で，給油系統の不具合などによる負圧の発生並 びにそれを起因とした絶縁破壊現象が $275 \mathrm{kVOF}$ 設備実機 を用いて確認されている(14)。また低圧ケーブルにおいてポ リ塩化ビニル (PVC) の経年による劣化現象が報告されて おり ${ }^{(15)}$ ，同様な防食層を保有している経年 OF ケーブルに おいても防食層劣化からアルミ被の孔食・漏油の発生が懸 念される。今後，これらの諸現象に注視し，必要に応じて 診断や諸対策を講じながら設備管理していく必要がある。

（2）ＣVケーブルの保全技術＼cjkstart現在確認できている $\mathrm{CV}$ ケーブルの劣化は，22-66 kV 級や $154 \mathrm{kV}$ 級などにお いて発生している水トリーによる絶縁性能の低下である。 これは遮水機能のないケーブルにおいて多く発生しており, これまでに水トリーを対象とした劣化診断技術が各種検討 され，既に損失電流高調波成分法や残留電荷法などが適用 


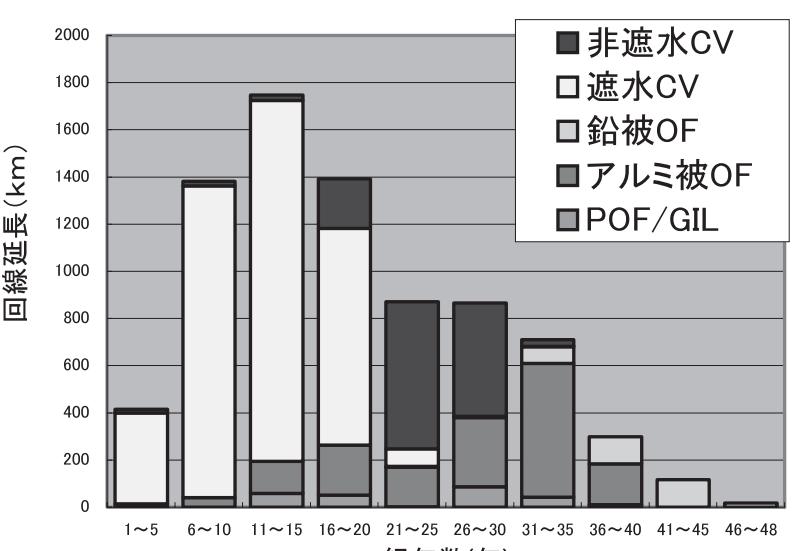

経年数(年)

図 4 東京電力の経年別設備量

Fig. 4. Amount of Cable classified by age (TEPCO).

を開始している ${ }^{(16)}$ 。これらについては, 今後更なる精度向 上や高機能化, そして活線測定や劣化位置の特定などが可 能な診断法の開発が望まれる。

現時点において水トリー以外の劣化現象については，ま た兆候は見られていない。電気学会技術報告第 668 号 ${ }^{(17)}$ に おいて遮水機能付き CV ケーブルの撤去調査を行ったが電 気破壊試験電圧值は初期值と殆ど変わらない結果が出てお り，水の浸入の無いケーブル寿命は 30 年を大きく上回る レベルまで期待できる見込みである。しかしながら，いず れは熱劣化などによる絶縁性能の低下が生じるものと想定 され，今後それらの劣化メカニズム把握や診断技術の開発 が望まれる。

（3） CV ケーブル用接続部の診断 最近において接 続部の施工欠陥による絶縁破壊事故はかなり減った。これ は施工品質を向上させた接続部や工法が開発されたことに よるものと想定される。現時点では接続部の初期欠陥検出 については, 超高圧線路の竣工時試験などで実施している 部分放電 (PD) 技術が主となっている。

一方, $\mathrm{CV}$ 線路も経年設備が増え, 終端接続部のプレモー ルド絶縁体表面に析出物発生やケーブル部の細り, 導体接 続の接触不良による局部温度上昇，シリコーン油中の可燃 性ガス発生などの劣化現象も散見されるようになった。こ のためトラブル未然防止の観点より，簡易型の PD 測定や 赤外線カメラを用いた温度診断, 油浸終端のシリコーン油 中ガス分析などの劣化診断が行われている ${ }^{(18)}$ 。今後, PD 測 定において一層のノイズ低減技術, 箔電極法の無停電での 診断技術などの開発が望まれる。また現在，プレハブ終端 のケーブル細りの影響, 析出物や温度変化によるプレモー ルド絶縁体面圧や挙動への影響について調査が開始されて おり，これらの知見が将来的に新たな診断法・寿命評価技 術の基となることが期待される。これらについても電気学 会「送電用 CV ケーブル用接続部の技術動向調査専門委員 会」にて鋭意検討が進められている。

\section{3. むすび}

日本の電力ケーブル技術は，世界を先駆けて $500 \mathrm{kVCV}$ ケーブル線路を実用化し, CV ケーブルの劣化診断技術の 導入を罒るなど，世界のトップクラスに位置している。こ れからは経年設備の診断やリプレースに合わせ，更なる新 技術の開発に期待を寄せたい。

(平成 18 年 1 月 14 日受付)

\section{文献}

（1）「OF ケーブルおよび CV ケーブルにおける高温性能とその支配要 因」, 電気学会技術報告, No.858 (2001)

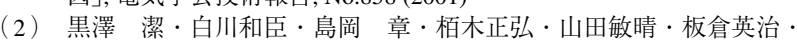
築山大輔：「光ファイバ電流センサを用いた地中線事故区間検出装 置の開発」, 平成 17 年電気学会全国大会, No.6-194 (2005)

（3）斎藤貴志・中出雅彦・加納俊哉・石川友直：「地中送電線埋設管路に おける新導体温度推定プログラムの開発」, 平成 14 年電気学会全国 大会, No.7-144 (2002)

（4） 岩崎公裕・戸谷 敦：「154kV 大サイズトリプレックス CV ケーブ ルの適用検討」, 平成 18 年電気学会全国大会 (2006)

(5) K. Kobashi, et al.: "Completion of prefabricated joint for $500 \mathrm{kV}$ XLPE cable", Jicable'03 A.5.4.

（6）「海外に扔ける送電用ケーブルの技術動向」, 電気学会技術報告, No.767 (2000)

（7）中嶋慎論・岩崎公裕・刈谷和市・中西辰夫：「66.77 kVCV ケーブル 用施工時間短縮型直線接続部（時短 RBJ）の開発」, 平成 17 年電学 電力・エネルギー部門大会 (2005)

（8）戸谷 敦, 他：「66/77 kV 次世代ガス中終端接続部の開発」, 平成 18 年電気学会全国大会 $(2006)$

（9）重次浩樹・田中 敦・岩崎公裕:「CV ケーブル接続部の現状と課題」, 平成 17 年電気学会全国大会シンポジウム, No.7-S16-1 (2005)

（10）西内 誠·迁 哲司・相島幸則・助川玩也·原 信：「77 kVCV ケー ブル用ポリマー碍管気中終端箱の開発」, 平成 13 年電気学会電力 エネルギー部門大会, p.489 (2001)

(11） 戸谷 敦·田中 敦・N. Mikli - M. Berth · 足立和久 · 瀬間信幸 · 辺見 清: 「66/77 kV ダイレクトモールド気中終端接続部の開発」, 平成 16 年電気学会全国大会, No.7-138 (2004)

(12) H. Honjo, Y. Takahashi, M. Hirose, S. Isojima, and H. Suzuki: "Verification Tests of a $66 \mathrm{kV}$ High-Tc Superconducting Cable System for practical Use", CIGRE 2002, SC-B1.21-143 (2002)

(13) M. Ichikawa, T. Takahashi, K. Suzuki, S. Mukoyama, M. Yagi, and A. Kimura: "Demonstration and verification tests results of 500-m HTS power cable”, 2005 National Convention Record IEE Japan, No.5 S15-4 (2005)

(14） 戸谷 敦 - 真下展宏 · 那須川慎介・嶋田光正 - 金岡 護：「275 kVOF ケーブル用実機接続部を用いた負圧時絶縁破壞特性の測定」, 平成 18 年電気学会全国大会 (2006)

（15）池田 毅・芦田哲哉・川崎勝利：「低圧ケーブル用超音波劣化診断器 の開発」, 電学論 B, Vol.120-B, No.11, pp.1437-1442 (2000-11)

(16) A. Toya, M. Nakade, Y. Okuyama, K. Uchida, Y. Yagi, and H. Kon: "Trends of Diagnostic Techniques for Deteriorated XLPE cable", The Papers of Joint Technical Meeting on Dielectrics and Electrical Insulation and Electric Wire and Power Cable, IEE Japan, DEI-05-35, EWC-05-1, pp.1-6 (2005)

（17）「特別高圧 CV ケーブル絶縁劣化形態と絶縁診断技術の動向」, 電気 学会技術報告, No.668 (1998)

（18）岩崎公裕・重次浩樹：「CV ケーブル用接続部の診断技術の現状と課 題」, 平成 18 年電気学会全国大会シンポジウム (2006)

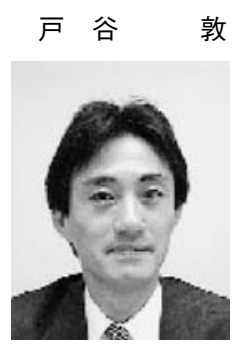

(上級会員) 1959 年 12 月 27 日生。1982 年 3 月 東京理科大学工学部電気工学科卒業。同年 4 月東 京電力 (株) 入社。現在電力流通本部工務部地中 線技術担当。主として地中送電システムの建設, 保守, 研究開発業務に従事。 